\title{
EDITORIAL: Killing the messenger
}

T

HE statistics globally are chilling. And the Asia-Pacific region bears the brunt of the killing of journalists with impunity disproportionately. Revelations in research published in this edition of Pacific Journalism Review on the trauma experienced by television journalists in the Philippines covering President Rodrigo Duterte's so-called 'war on drugs', or as many describe it, a 'war on poverty', with more that 12,000 dead is deeply disturbing (Amnesty International, 2017). While these deaths, allegedly mostly extrajudicial killings, do not relate directly to the murders of journalists, the highest death toll ever of journalists in a mass execution took place in the southern Philippines almost nine years ago.

Justice has yet to be served for the savage killing of 32 journalists in an ambush - among a larger group of 58 people in an electoral convoy, including two human rights lawyers - on the island of Mindanao on 23 December 2009. In spite of more than 150 witnesses and 'thousands of pages of documentary evidence' being presented before a special court in the case known as the Maguindanao Massacre, no verdict has yet been brought against any of the 195 accused (Mateo, 2015; PCIJ, 2016). The Philippine Star reported that for Maguindanao governor Esmael Mangudadatu, who lost his wife Genalyn and two sisters in the ambush, along with a number of female lawyers and staff, 'justice is still an elusive dream'. As the Philippine Centre for Investigative Journalism noted in an analysis seven years after the massacre:

\footnotetext{
The trial ... was designed for delay, a nod to another political alliance. A lengthy trial allows more time for highly paid lawyers to manipulate the court system, argue through technical loopholes. Delays can wear down or lose witnesses and their testimonies. Sanctioned by the rules of court, the system seems designed only for lawyers and those who can afford them. (PCIJ, 2016)
}

In December 2013, the Supreme Court passed a resolution enabling the judge to decide cases against the accused separately. But no judgments have been made against the killers of the journalists and two prosecution witnesses have been killed in the past eight years.

According to UNESCO, about 1,010 journalists globally have been 'killed for reporting the news and bringing information to the public' in the 12 years until 2017 - or on average, one death every four days (UNESCO, n.d.). 'In nine out of ten cases the killers go unpunished. Impunity leads to more killings and is often a symptom of worsening conflict and the breakdown of law and the 
judicial systems.' Many argue that the Philippines, with one of the worst death tolls of journalists in the past decade, is an example of this breakdown. In addition to the 'drug war' killings, President Duterte has extended martial law on Mindanao in the wake of the five-month battle of Marawi in 2017, in which a historical Muslim city was gutted and destroyed (and an Australian journalist was wounded by a sniper and more than 1,000 people were killed). The president has also waged a vindictive war on the critical news website Rappler and daily newspaper Philippine Daily Inquirer (now owned by a business crony); and critics increasingly liken him to the dictator Ferdinand Marcos.

Compared with the Philippines and some other Asian countries, such as Cambodia, Indonesia and Myanmar, media freedom issues in the Pacific microstates and neighbouring Australia and New Zealand may appear at first glance relatively benign and certainly not life threatening. Nevertheless, the Pacific faces growing media freedom challenges as demonstrated by the Micronesian state of Nauru which banned the Australian public broadcaster, 'arrested' Television New Zealand Pacific correspondent Barbara Dreaver (albeit only detaining her for four hours) while she was covering the Pacific Islands Forum leaders' summit in September 2018 and tried to gag other journalists from reporting allegations of human rights violations against asylum seekers in Australian detention centres on the island. Several countries in the Pacific, notably Fiji, Papua New Guinea and Samoa, are also using tougher legislation to clamp down on media, especially the internet.

In this context, Auckland University of Technology's Pacific Media Centre marked its tenth anniversary in November 2017 with a wide-ranging public seminar discussing two of the region's most critical media freedom crises. The 'Journalism Under Duress in Asia-Pacific' seminar in November 2017 examined media freedom and human rights in the Philippines and in West Papua. Invited speakers were the PCIJ's executive director Malou Mangahas from the Philippines and Johnny Blades of RNZ Pacific. Mangahas recalls how the global financial crisis fed into media freedom issues in the Southeast Asian region:

In 2007, when the Pacific Media Centre was born I thought the world was in
a better place, but actually Wall Street wasn't. So there will be crises every so
often and some things will turn out okay politically or in the political sphere
because at that time there was some opening up in some countries but not
in other parts of the Pacific. So now it's 2017 and what we see perhaps is a
bigger role for groups like the Pacific Media Centre because what we are
observing in the region is a general pushback. (Mangahas, 2017)

The hosting of this seminar and the publication of research papers and commentaries in this edition of $P J R$ have been planned in recognition of the International Day To End Impunity for Crimes Against Journalists, which has been 


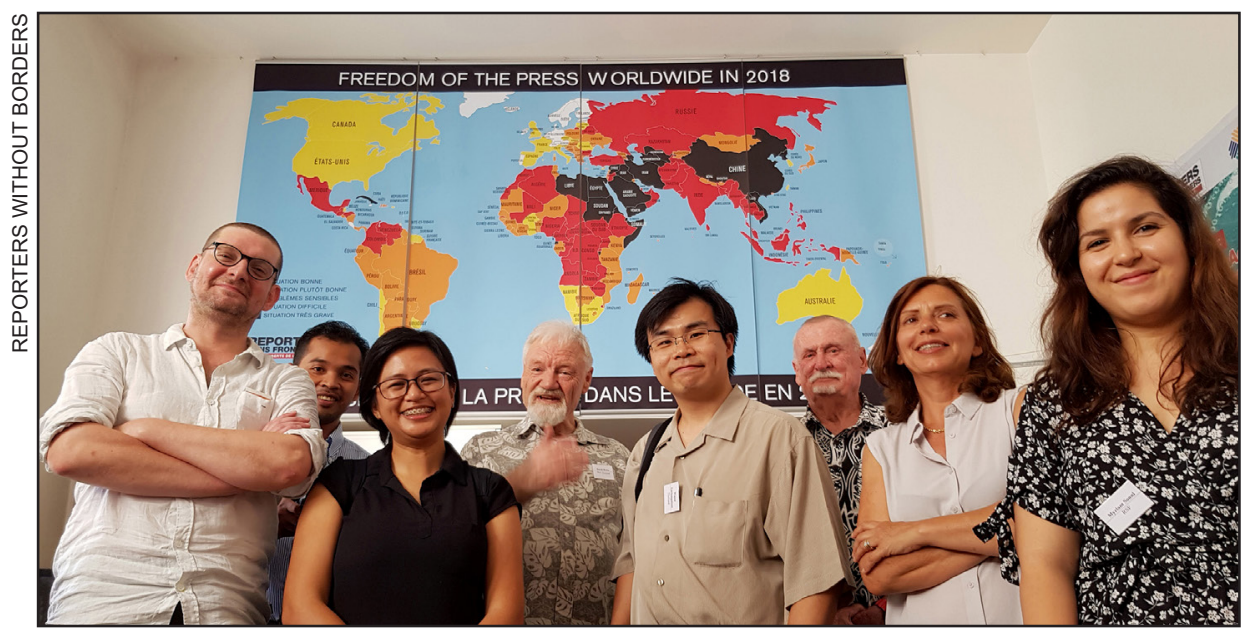

Figure 1: Asia-Pacific media freedom advocates, including Pacific Journalism Review editor David Robie (centre), at a Reporters Without Borders strategic consultation in Paris, France, in July 2018.

marked annually on November 2 since it was declared by UNESCO in 2013, and as a reflection of a growing body of academic research about the safety of journalists (George, 2017).

The introduction by David Robie to the PMC seminar, later presented at a Reporters Without Borders summit for Asia-Pacific freedom advocates and activist journalists in Paris in July 2018 (Figure 1), offers an overview of the culture of impunity over crimes against journalists and journalism safety as a major factor undermining media freedom in the region.

Access to the Indonesian region of West Papua (Papua and West Papua provinces) for foreign journalists, while still restricted, remains critical for helping Papuan voices to be heard. Johnny Blades of RNZ Pacific argues that the plight of West Papua is of major concern among Pacific people, especially Melanesians, and is becoming a growing geopolitical and media issue.

In the Philippines, journalists covering the 'graveyard shift' were the first recorders of violence and brutality under Philippine President Rodrigo Duterte's anti-illegal drugs campaign. The first phase in 2016, called Oplan Tokhang, was executed ruthlessly and relentlessly. This chilling study by ABS-CBN news executive Mariquit Almario Gonzalez examines how graveyard-shift TV journalists experienced covering Oplan Tokhang. The intention is to get a deeper understanding of how the experience affected the way they reported on the Oplan Tokhang stories.

Her colleague, award-winning photographer Fernando Sepe Jr, has contributed an associated photoessay drawn from his groundbreaking 'Healing The Wounds From the Drug War' gallery. He reflects on the impact of Duterte's socalled 'War on Drugs' onslaught on the poor in his country: 
The families of the dead, mostly from the poor who get by in hand-tomouth existence, end up buried in debt only to have their loved ones get a burial. But it also a story of hope for those given a new lease of life by organisations willing to assist in the rehabilitation of drug addicts. (p. 147)

Across the Pacific, there have been startling news stories about governments attempting to censor the internet, a move seen to point towards silencing dissenting views on popular online forums. Romitesh Kant, Jason Titifanue, Jope Tarai and Glenn Finau demonstrate how conflicting trends between the new political forum ushered in by the new media on the one hand, and the restrictive mode of state censorship on the other hand, pose serious challenges to the broader framework of rights and freedom of expressions, especially in Fiji, Papua New Guinea and Samoa.

In a separate commentary, Jope Tarai explores the Fiji situation in more depth and provides compelling evidence that the public has been 'conditioned' to accept the new Online Safety Act 2018. However, he questions this law and argues that it has been a subtle form of online regulation ushered in under a cloak of 'online safety'.

In Indonesia, Nasya Bahfen and Febri Nurrahmi examine the representation of Acehnese identity post-civil conflict and in relation to national identity of the republic by drawing on a content analysis of the local newspaper Serambi Indonesia.

In Timor-Leste, Australian media consultant and press freedom advocate Bob Howarth reflects on two days of presentations and roundtable discussions which ushered in the capital, Dili, as the hub for a proposed alliance of Asia-Pacific press councils committed to raising media standards and providing freedom of information benchmarks.

In Australia, whistleblower advocate Brian Martin deconstructs a case study of how a media hatchet job, or beat-up, by a daily newspaper, in this case the Daily Telegraph, can have a disportionately damaging impact in an academic environment. This commentary, and the evidence presented, is a disturbing revelation in the context of a series of attacks on journalism academics and researchers from Suva to Sydney.

In the wake of the Fifth Pacific Media Summit in Nuku'alofa, Tonga, in May 2018, Geraldine Panapasa and Shailendra Singh analyse how journalists and media policymakers are responding to growing efforts by governments in the Pacific region to deploy ever harsher media legislation to 'contain the fallout from social media, citizen journalism and fake news'.

Finally, rounding off the 'journalism under duress' themed section, Joseph Fernandez was present in Doha for a global media freedom conference in July 2017 in the wake of a 'brazen attack on media freedom' by a Middle East bloc led by Saudi Arabia and the United Arab Emirates (UAE) that demanded (among 
other things) the shut down of the Al Jazeera television network. He analyses the media responses for Pacific Journalism Review.

WHILE there is no 'Frontline' (journalism-as-research) section in this edition of Pacific Journalism Review, there is a strong unthemed section, opening with a study of representations of 'the other' in New Zealand and how the Muslim voice is neglected. This article by Khairiah A. Rahman and Azadeh Emadi identifies a growing trend of stories in the New Zealand media relating to 'Islamic terrorism' and critically analyses a random sampling of five news articles between 2014 and 2016 in terms of the negative, positive and ambivalent news content, both in their use of the written text and visual representations of Islam and Muslims.

A Philippines qualitative research study over the development of a model on 'ASEAN-centred journalism and journalism education' has revealed countrylevel 'realities' that need to be faced before proceeding, argue Jeremaiah M. Opiniano and his University of Santo Tomas student colleagues Aira l. Bagtas, Karl C. Basco, Ralph J. Hernandez, Elyssa, C. Lopez, Michael C, Rodolfo and Anne K. Vicho.

In Micronesia, research fellow Sylvia C. Frain of the Pacific Media Centre examines the implications of the Make American Secure Appropriations Act 2018 and recent United States federal policy in the Marianas Archipelago. She critiques the expanding militarisation of the region and the construction of bombing ranges on the islands of Guam, Pågan and Tinian.

In the final unthemed paper, investigative journalist Michael S. Smith analyses the framing of the surge in illegal rhino poaching in South Africa linked to an increasing demand for rhino horn in Vietnam. One of the key frames is 'Voodoo Wildlife Parts,' which has been deployed by environmental non-government organisations (ENGOs) in their campaigns against the illegal trade.

This edition of Pacific Journalism Review has another strong review section. Books being discussed include recently appointed UNESCO chair for journalism in Australia Peter Greste's The First Casualty: From the Front Lines of the Global War on Journalism, and two new books with contrasting insights into West Papua-Peter Bang's Papua Blood and Maire Leadbeater's See No Evil. Humour in the media gets an airing with a review of The Funniest Pages and life as a foreign correspondent in Moscow Calling.

\section{Professor David Robie}

Editor

Pacific Journalism Review

www.pjreview.info 


\section{References}

Amnesty International. (2017). 'If you are poor, you are killed': Extrajudicial executions in the Philippines' 'war on drugs'. Retrieved from https://www.amnesty.org/download/ Documents/ASA3555172017ENGLISH.PDF

George, C. (2017). Special issue on the safety of journalists. Media Asia, 44(1), 1. Retrieved from https://doi.org/10.1080/01296612.2017.1394670

Mangahas, M. (2017). Journalism under duress in Asia-Pacific - the seminar. [Video] Auckland University of Technology, 30 November 2017. Retrieved from https://www. youtube.com/watch? $\mathrm{v}=\mathrm{ksSzcJc} 0 \mathrm{MnA}$

Mateo, J. (2015). 6 years later, still no justice in Maguindanao massacre. The Philippine Star. Retrieved from https://www.philstar.com/headlines/2015/11/22/1524946/6-yearslater-still-no-justice-maguindanao-massacre

PCIJ. (2016). Year seven after the massacre: Still no justice on sixth year of trial. Philippine Center for Investigative Journalism (PCIJ). Retrieved from http://pcij.org/ blog/2016/11/24/year-seven-after-the-massacre-still-no-justice-on-sixth-year-of-trial

UNESCO. (n.d.). International day to end impunity for crimes against journalists. United Nations Educational, Scientific and Cultural Organisation. Retrieved from https:// en.unesco.org/commemorations/endimpunity 